\title{
POLLITITIKK

\section{Norges debatt om kinesiske investeringer: Fra velvillig til varsom}

\author{
Bjørnar Sverdrup-Thygeson \\ Forsvarsstaben \\ Espen Mathy \\ Norsk Utenrikspolitisk Institutt (NUPI)
}

\begin{abstract}
Sammendrag
Den norske debatten om kinesiske investeringer og sikkerhet har gjennomgått et betydelig taktskifte på få år. Fra en situasjon hvor det i liten grad var en debatt, og hvor kritiske røster i hovedsak angikk bekymringer om arbeidsmiljøutfordringer, har kinesisk næringsvirksomhet i Norge nå også blitt en del av den sikkerhetspolitiske debattsfæren. To særtrekk giør det norske eksempelet til en spesielt interessant studie av de fellesnordiske spørsmålsstillingene diskutert i denne Fokusspalten. Norsk økonomi har tjent særegent godt på det kinesiske veksteventyret, men Norge har også stått i en særegent vanskelig politisk stilling overfor Kina gjennom det siste tiåret. Kontrasten mellom disse to faktorene har stått sentralt i norsk Kina-debatt. Ikke desto mindre har den norske offentlige debatten rundt kinesiske investeringer vært relativt positiv. Dette har blant annet vært drevet frem av gode erfaringer blant norske selskaper som har blitt kjøpt opp av kinesiske partnere. Den offentlige samtalen har dog i nyere tid begynt å relatere til spørsmålet gjennom en politisk og sikkerhetsmessig vinkling. Dette er et taktskifte som ikke skyldes hendelser knyttet til eksisterende kinesisk aktivitet i Norge, men heller en norsk gjenspeiling av bredere globale og regionale trender. Huaweis rolle i den kommende utbyggingen av 5G-nettverket har vært et spesielt viktig bindeledd til denne internasjonale opinionsdreiningen.
\end{abstract}

\footnotetext{
^Kontaktinformasjon: Bjørnar Sverdrup-Thygeson, e-post: bjornar.sverdrup-thygeson@oxon.org (C2020 Biørnar Sverdrup-Thygeson og Espen Mathy. This is an Open Access article distributed under the terms of the Creative Commons Attribution 4.0 International License (http://creativecommons.org/licenses/by/4.0/), allowing third parties to copy and redistribute the material in any medium or format and to remix, transform, and build upon the material for any purpose, even commercially, provided the original work is properly cited and states its license. Citation: Bjørnar Sverdrup-Thygeson og Espen Mathy (2020). Norges debatt om kinesiske investeringer: Fra velvillig til varsom. Internasjonal Politikk, 78(1): 79-92. http://dx.doi.org/10.23865/intpol.v78.2078
} 


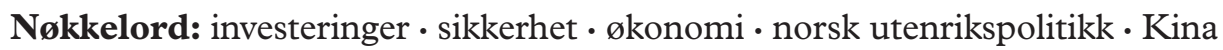

\section{Introduksjon}

Da relasjonene mellom Norge og Kina ble normalisert sent i 2016, fulgte en hektisk reisevirksomhet til Kina av delegasjoner fra norsk politikk og næringsliv. Blant norske bedrifter var optimismen spesielt stor overfor mulighetene dette åpnet for økte kinesiske investeringer. Selv rett i etterkant av at kinesiske myndigheter hadde utsatt Norge for en seksårig isfront etter fredsprisutdelingen til Liu Xiaobo, ble kinesiske investeringer og oppkjøp i hovedsak omtalt som en stor økonomisk mulighet. Spådommer om en kommende kinesisk kapitalflom ble omtalt i gullkantede vendinger i ledende næringslivsaviser (Aga, 2017; Havnes, 2017; NTB, 2017). Samtidig var det kinesiske teleselskapet Huawei allerede dypt inne i utbyggingen av det norske 4Gmobilnettet, uten at dette avstedkom noen større virak i den nasjonale offentligheten (Kibar, 2019). Denne relativt ukritiske holdningen til potensielle sikkerhetsaspekter ved kinesiske investeringer endret seg i løpet av noen få år til en langt mer avventende holdning. Huaweis rolle i utbyggingen av det nye 5G-nettet har blitt en politisk het potet og har skapt debatt i brede kretser. I takt med en holdningsendring som har funnet sted blant både nordiske og europeiske partnere, og ikke minst i USA, befinner vi oss nå i en situasjon hvor screeningmekanismer utvikles og debatteres, og norsk sikkerhetslovgivning endres i retning av å bli mer relevant for utenlandske investeringer.

Denne artikkelen bidrar til å kartlegge den norske debatten om dilemmaene som ligger i skjæringspunktet mellom nasjonal sikkerhet og åpenhet for investeringer fra Kina. Som de øvrige kapitler i dette fokusnummeret demonstrerer, er dette en debatt som har seilt opp på dagsordenen på bred basis, både blant våre nordiske naboland og ellers i verden. Artikkelen diskuterer denne spørsmålsstillingen langs tre hovedlinjer. Først vil det gis en gjennomgang av det politiske og økonomiske bakteppet for den pågående debatten. Dette innbefatter å kartlegge den nåværende situasjonen for kinesiske kapitalstrømmer til Norge. Hvor stort er omfanget av kinesiske direkteinvesteringer til landet, og mot hvilke økonomiske sektorer er de rettet? På bakgrunn av denne konteksten vil den andre hoveddelen ta for seg den norske offentlige debatten om forholdet mellom sikkerhet og kinesiske investeringer. For å kartlegge den tidligere nevnte dreiningen av den norske offentlige samtalen om investeringer og sikkerhet har vi først gjennomført en kvantitativ kartlegging og koding av norske medieoppslag i årene 2009-2018. Analysen av dette tallmaterialet vil så bli ytterligere supplert ved å se noe mer i detalj på to enkeltsaker, nemlig debatten rundt Huaweis rolle som utbygger av norske telenettet og det kinesiske oppkiøpet av Elkem. Disse to sakene er av spesiell interesse, for det første fordi mediakartleggingen viser at dette er to av de mest omtalte eksemplene på kinesisk næringsvirksomhet i Norge. For det andre er disse selskapene også nøkkeleksempler på henholdsvis de samfunnssikkerhetsmessige spørsmålene samt de økonomiske 
gevinstene som kinesiske investeringer kan frembringe. Den tredje delen vil så ta for seg de politiske prosessene rundt de pågående endringer i norsk lovgivning som er relevante for sikkerhetsaspekter ved utenlandske investeringer. Denne debatten fremviser hvordan det politiske Norge har søkt å manøvrere det sentrale dilemmaet en liten, åpen økonomi står overfor, i en verden preget av økende konfrontasjon også i den økonomiske sfæren. I sum har den norske debatten om kinesiske investeringer gjennomgått et betydelig taktskifte på få år. Fra en situasjon hvor det i liten grad var en debatt overhodet, og hvor kritiske røster i hovedsak fremmet bekymringer om arbeidsmiljøutfordringer, har kinesisk næringsvirksomhet i Norge nå også blitt en del av den sikkerhetspolitiske debattsfæren.

\section{Politisk og økonomisk kontekst}

Norge er det landet i Europa som har tjent mest på Kinas økonomiske fremvekst (Melchior, 2018). Den "doble Kina-effekten» av økt pris på norske eksportvarer, som olje, og reduserte priser på norsk import, så som klær og sko, har dermed vært en kraftig driver for den norske økonomiske boomen etter årtusenskiftet (Bekkevold \& Kristoffersen, 2012; Laustsen, 2014). Norges særstilling med en økonomisk struktur som gjorde det mulig å hente ut en særskilt stor velstandsøkning fra Kinas integrasjon med verdensmarkedet, har dog i den senere tid også blitt kombinert med en annen særstilling som det nordiske landet som mest akutt har fått føle konsekvensene av politiske uoverensstemmelser med Kina. Norge var, i likhet med de fleste nordiske landene, blant de første vestlige land som anerkjente folkerepublikken Kina på 50-tallet. Årene siden har hatt sin del av opp- og nedturer, med et spesielt betydningsfullt tilfelle av politisk spenning i 1989 etter fredsprisutdelingen til Dalai Lama (Øgrim \& Nilsen, 2015; Sverdrup-Thygeson, 2017; Utenriksdepartementet, 2011).

Mest skjellsettende hva angår den politiske konteksten i norsk-kinesiske relasjoner de siste årene, er dog de seks årene etter at den norske Nobelkomiteen i 2010 delte ut Nobels fredspris til den fengslede kinesiske dissidenten Liu Xiaobo. I seks år boikottet Beijing likeledes all bilateral politisk kontakt og la hindringer i veien på en rekke økonomiske felt, først og fremst i den symbolsk viktige lakseeksporten til det kinesiske forbrukermarkedet (Chen et al., 2015; Gåsemyr, 2018; Sverdrup-Thygeson, 2015). Selv om det på langt nær var første gang Kina tok i bruk slike virkemidler mot et europeisk land, var varigheten og bredden i den kinesiske sanksjoneringen av et nær enestående omfang. Etter flere forsøk på å løse situasjonen under påfølgende norske regjeringer ble forholdet til slutt erklært normalisert i desember 2016, etter at de to lands regjeringer kom til enighet om en offisiell firepunktserklæring der Norge blant annet erklærte at de vil «do its best to avoid any future damage to the bilateral relations» (Government of Norway and Government of PRC, 2016). I rask rekkefølge ble så Norges statsminister, den norske kongefamilien og Stortingets utenriks- og forsvarskomite mottatt på offisielt besøk i Beijing, frihandelsforhandlingene ble gjenopptatt, og Li Zhanshu kom i mai 2019 på et offisielt gjenbesøk til Norge (J. Lohne, 2017; NRK, 2017a; NTB, 2019). I takt med at den politiske kontakten 
ble gjenopptatt, ble også forhandlingsrundene om en frihandelsavtale mellom de to landene tatt opp igjen, etter at de hadde vært lagt på is i seks år. Etter å ha vært nær en sluttføring før 2010 er prosessen nå oppe og går igjen, med den 16. forhandlingsrunden nylig gjennomført. Mens norske myndigheter tydelig har signalisert sine preferanser for å øke tilgangen for norsk sjømat på det kinesiske markedet, er dog spørsmålene om rammevilkårene for kinesiske investeringer ennå uavklart (Fiskeridepartementet, 2019).

\section{Kinesiske investeringer i Norge}

På tross av de økonomiske og politiske særegenhetene beskrevet ovenfor, er det interessant å bemerke at kinesiske investeringsmønstre i Norge i stor grad likevel har fulgt det samme mønsteret som i de andre nordiske landene. Det totale volumet av kinesiske investeringer har jevnt over ligget på linje med resten av Norden og reflekterer den samme betydelige økningen fra et lavt nivå i løpet av de to siste tiårene. I likhet med hva som er tilfellet ellers, er også i Norge det totale nivået relativt lavt sammenlignet med antall investeringer fra andre nordiske og europeiske land i tillegg til USA (ETNC, 2017). Kina rangerer for øyeblikket mellom 10. og 15. plass på listen over land med de største FDI-beholdningene i Norge. Gitt at Norge ikke er EU-medlem, er ikke landet inkludert i oversikten til Rhodium Group, som danner datagrunnlaget for de danske, finske og svenske bidragene til denne fokusspalten, men et tidligere NUPI-prosjekt har sammenstilt og triangulert informasjon fra en rekke kilder til en oversikt over kinesiske M\&A (mergers and aquisitions) i Norge (Gåsemyr \& Sverdrup-Thygeson, 2017). For en oversikt over alle kjente større investeringer (over 100 millioner dollar i verdi), se tabell 1.

Tabell 1. Hovedtransaksjoner - kinesiske investeringer i norske selskaper, 2002-2018. ${ }^{1}$

\begin{tabular}{l|l|l|l|l}
\hline $\begin{array}{l}\text { Oppkjøp } \\
\text { fullført, år }\end{array}$ & Kinesisk investor & Norsk selskap & $\begin{array}{l}\text { Investeringens } \\
\text { størrelse, mill. } \\
\text { USD (eierandel) }\end{array}$ & $\begin{array}{l}\text { Økonomisk } \\
\text { sektor }\end{array}$ \\
\hline 2003 & Sinochem & Atlantis & $105(100 \%)$ & Energi \\
\hline 2008 & $\begin{array}{l}\text { COSL Norwegian, } \\
\text { CNOOC }\end{array}$ & Awilco Offshore & $2500(100 \%)$ & Energi \\
\hline 2010 & $\begin{array}{l}\text { Grand China Logistics, } \\
\text { HNA }\end{array}$ & $\begin{array}{l}\text { Offshore Heavy } \\
\text { Transport }\end{array}$ & $380^{\star}(60 \%)$ & Transport \\
\hline 2011 & $\begin{array}{l}\text { China Bluestar, } \\
\text { ChemChina }\end{array}$ & Elkem & $2000(100 \%)$ & Kjemikalier \\
\hline 2015 & $\begin{array}{l}\text { Bluestar Elkem } \\
\text { Investment, ChemChina }\end{array}$ & REC Solar & $640(100 \%)$ & Energi \\
\hline 2016 & Reignwood & Voss Water & $105^{\star}(55 \%)$ & Forbruker \\
\hline
\end{tabular}

1 Kilder: Rhodium Group, American Enterprise Institute, Zephyr Investment Management og Gåsemyr \& Sverdrup-Thygeson, 2017. 


\begin{tabular}{l|l|l|l|l}
\hline $\begin{array}{l}\text { Oppkjøp } \\
\text { fullført, år }\end{array}$ & Kinesisk investor & Norsk selskap & $\begin{array}{l}\text { Investeringens } \\
\text { størrelse, mill. } \\
\text { USD (eierandel) }\end{array}$ & $\begin{array}{l}\text { Økonomisk } \\
\text { sektor }\end{array}$ \\
\hline 2016 & $\begin{array}{l}\text { Golden Brick, Qihoo and } \\
\text { Beijing Kunlun }\end{array}$ & $\begin{array}{l}\text { Opera Software } \\
\text { (consumer division) }\end{array}$ & $575(100 \%)$ & Data og IT \\
\hline 2018 & $\begin{array}{l}\text { Qumei Home } \\
\text { Furnishing, Huatai } \\
\text { Securities }\end{array}$ & Ekornes & $630(100 \%)$ & Forbruker \\
\hline
\end{tabular}

Rapportering og anslag av endelig pris varierer mellom kildene, det mest konservative anslaget er valgt. Merk at figuren ikke oppgir mindre investeringer som har funnet sted.

På bakgrunn av de tilgjengelige dataene anslås verdien av kinesiske direkteinvesteringer (mergers and aquisitions) i Norge til et sted mellom fem og seks milliarder euro. Dette inkluderer dog ikke greenfield-investeringer eller kontraktsbaserte oppdrag. Som figuren ovenfor illustrerer, er det en del brede trender som trer frem i det norske tilfellet, som også er representative for mer generelle trender i kinesiske FDI både globalt og regionalt i Europa. Mens kinesisk M\&A-aktivitet på tidlig 2000-tallet var fokusert på oppkjøp relatert til naturressurser og energisektoren, har oppkjøpene siden 2010 hatt et spesielt fokus på ledende aktører med teknologisk spisskompetanse innen mer spesialiserte sektorer. Kinesiske statlig eide selskaper fortsetter også å være den dominerende aktøren på feltet.

I sum er nivået av kinesiske investeringer i Norge på rundt det samme nivået som for de andre nordiske landene, noe som gjenspeiler hvordan regionen som helhet til nå har spilt en sekundær rolle som mottaker for kinesiske investeringer $\mathrm{i}$ Europa (ETNC, 2017; Hellström, 2014, 2016). Ringvirkningene av det stormfulle politiske og diplomatiske forholdet er vanskelig å anslå på bakgrunn av et så vidt lite antall caser, men gitt at investeringsflyten ikke har skilt seg overveldende fra den bredere nordiske trenden, later virkningen til å ha vært begrenset. Det kan dog ikke utelukkes at flere kinesiske investeringer kunne ha skjedd i løpet av de siste årene, hadde situasjonen vært en annen. Likevel, som illustrert i figur 1, var ikke den politiske situasjonen til hinder for noen av de mest betydningsfulle kinesiske oppkjøpene i Norge. Dette er også i tråd med bredere observasjoner om at den politiske boikotten av Norge i mindre grad hadde en effekt på de økonomiske sektorene Kina anså som viktige for sin innenlandske utvikling (Sverdrup-Thygeson, 2015). Et forventet «investeringsrush» $\mathrm{i}$ tiden etter normaliseringen av forholdet i 2016 har, med unntak av et oppkjøp av den norske møbelfabrikanten Ekornes, foreløpig heller ikke manifestert seg (NTB, 2017).

\section{Den offentlige debatten om kinesiske investeringer}

I den senere tiden har bredere globale trender, spesielt det stadig mer spente forholdet mellom USA og Kina, tilført et ekstra lag av politisk kompleksitet til spørsmålet om kinesiske investeringer i Norge. I flere land i Europa har det de siste årene 
vært økende offentlig debatt om og kritisk søkelys rettet mot kinesiske investeringer. Dette har også kommet til uttrykk i den norske debatten rundt disse investeringene. Den norske offentlige debatten rundt kinesiske innenlandske investeringer har lenge vært relativt begrenset, og investeringer i norske selskaper har ofte vært omtalt i positive ordelag. En kvantitativ analyse av det norske offentlige ordskiftet rundt kinesiske investeringer i Norge illustrerer tydelig denne trenden, som sett i figur $1 .^{2}$ Man kan spore en topp i 2011, rundt storoppkjøpet av Elkem, men ellers har dekningen ligget på et relativt lavt nivå, frem til et betydelig oppsving av medieoppmerksomhet rundt kinesiske kapitalstrømmer fra 2016 og fremover, som samsvarer med normaliseringen av det norsk-kinesiske forholdet.

Man kan dog se et noe mer kritisk søkelys på disse spørsmålsstillingene, og figur 2 illustrerer hvordan medienes dekning har gått fra å være relativt fraværende, til i økende grad å fokusere også på potensielt negative effekter av kinesiske kapitalstrømmer til Norge. Antall artikler som omhandler sikkerhetsaspekter ved kinesiske investeringer i Norge, har vist en tilsvarende økning i årene 2012 til medio 2019, fra et nivå da dette aspektet var nesten fraværende fra nyhetsbildet. Det totale antallet er fortsatt lavt.

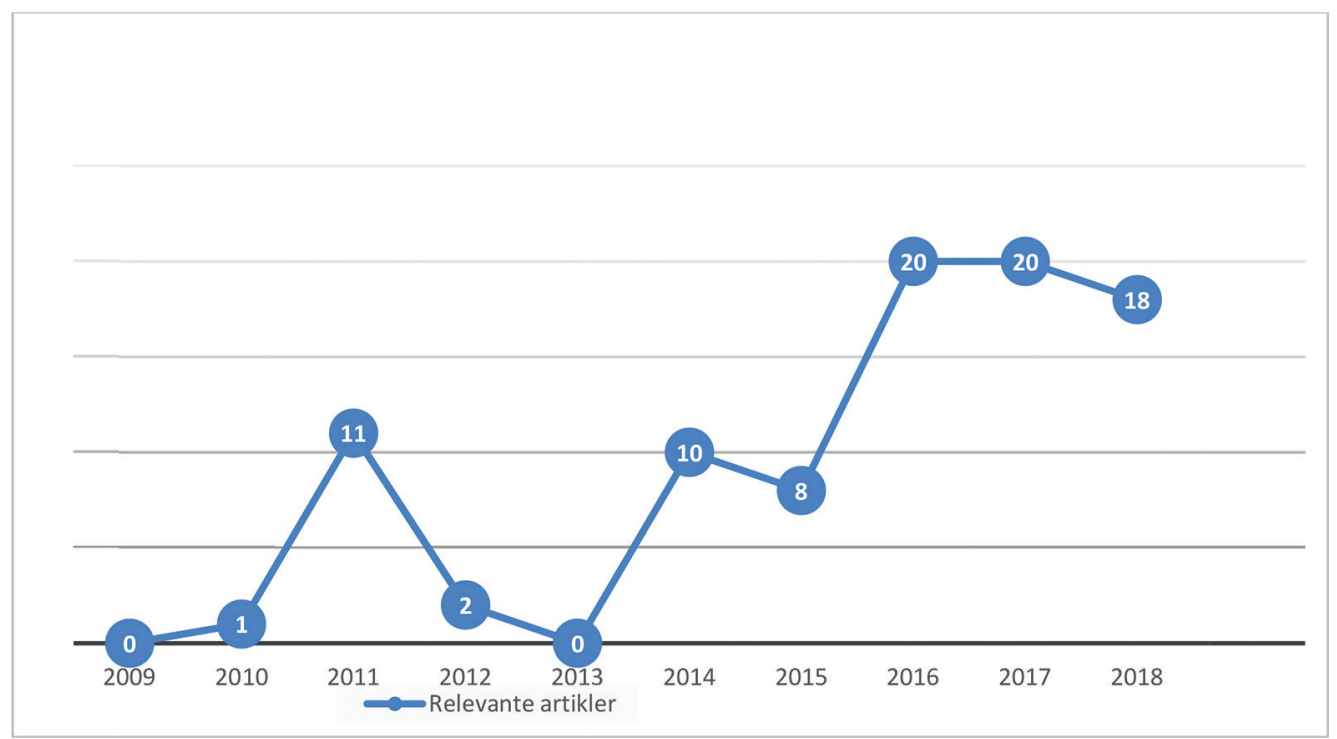

Figur 1 Antall artikler i ledende norske nyhetsmedier som omhandler kinesiske investeringer i Norge, 2009-2018. Søkestreng: «kinesisk ${ }^{\star}$ investering $\star$ and (norsk or norge).

2 Den kvantitative kartleggingen som ligger til grunn for denne artikkelen, er basert på en full gjennomgang av alle norske avisartikler publisert om kinesiske investeringer i Norge i årene 2009 til medio 2019. Disse er identifisert gjennom trunkerte søk i Retreivers norske tidsskriftdatabase. Treffene er deretter gjennomgått manuelt for innholdskoding, og irrelevante artikler, NTBartikler kopiert i andre medier, duplikater fra internett- og papirmedier samt spesialiserte bransjemedier er luket ut. Figur 1 viser treff på søkestrengen 2009-2019: "kinesisk ${ }^{\star}$ investering $^{\star}$ » and (norsk or norge), etter utluking av dubletter og irrelevante treff. 


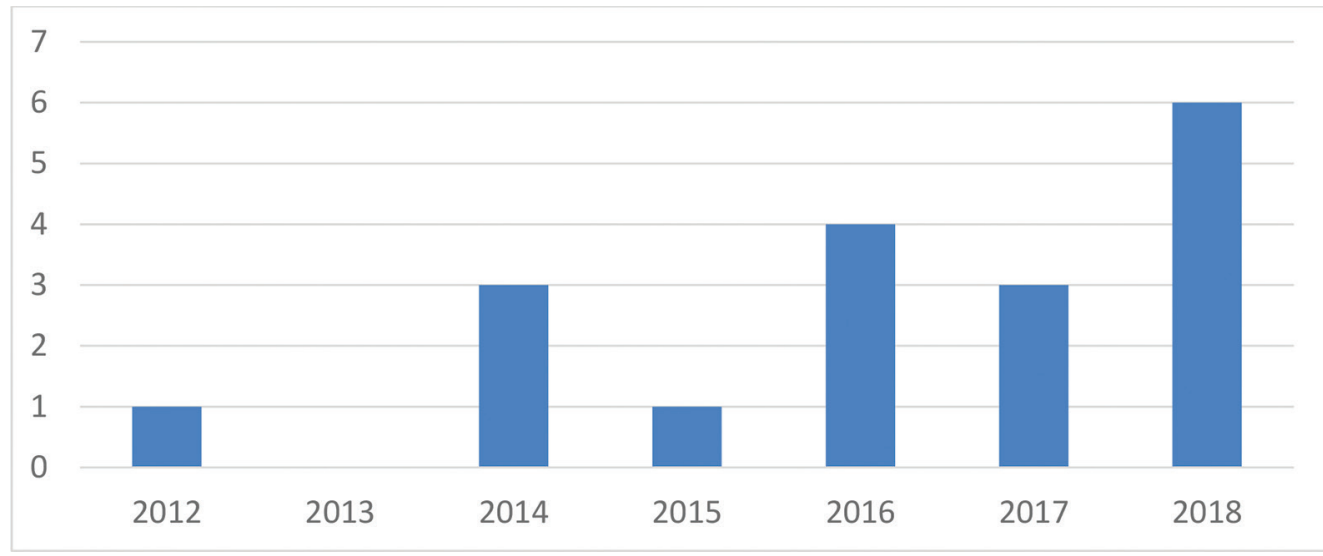

Figur 2 Antall artikler som omtaler sikkerhetsaspekter.

Medienes omtale har fra starten av vært spesielt kritisk til kinesisk kapitaltilstrømning hva angår tre ulike temaer. Først og fremst gjelder dette investeringer eller kinesisk inntreden i sektorer som har relevans for nasjonal sikkerhet og beredskap. Teleselskapet Huawei har her, naturlig nok, vært det springende punkt for den norske avleggeren av den bredere vestlige debatten om potensielle sikkerhetsutfordringer ved bruk av kinesisk teknologi i utbyggingen av norske telenett (Breian, 2019; NRK, 2019; NUPI, 2019). Det var noe debatt i forbindelse med at Huawei fikk konsesjon på utbygging av 4G-nettverket fra 2009 og senere, men denne debatten forgikk relativt raskt (Kibar, 2019). Imidlertid har Huawei og prosessen rundt konsesjoner for utbyggingen av 5G-nettet nylig ført til at kinesiske selskaper i Norge for første gang har blitt et viktig tema i den nasjonale politiske og offentlige debatten.

I nesten halvparten av artiklene identifisert i den kvantitative analysen gjennom Retriever, der sikkerhetsaspekter er omtalt, er også Huawei omtalt. Dette illustrerer Huaweis posisjon som en nøkkelsak, som belyser det stadig økende og mangefasetterte presset for å finne politiske og administrative svar på et helt nytt sett med utfordringer i skjæringspunktet mellom nasjonal sikkerhet, ny teknologi og geopolitiske endringer. En viss debatt har også vært å spore rundt kinesiske investeringer i norsk petroleumssektor, men dette har enn så lenge vært svært lite fremme i media (A. K. J. Lohne, 2017). Det andre området hvor kritiske stemmer har blitt målbåret med hensyn til kinesisk FDI, angår enkelte politikeres og fagforeningers bekymring for at kinesiske eiere av norske bedrifter vil kunne bidra til å svekke etablerte arbeidsrettigheter. Dette var noe fremme i media ved overtakelsen av Elkem, men disse bekymringene har siden blitt lagt til ro, og de relevante arbeidstakerforeninger har uttrykt positiv tilfredshet med arbeidsforholdene etter oppkjøpet (Lier, 2011). Det tredje området hvor det har vært negativ medieoppmerksomhet, er relatert til det tidligere nevnte spørsmålet om sikkerhetshensyn og angår noen høyt profilerte planer på vegne av den kinesiske investoren Huang Nubo om å kjøpe eiendommer i Norges arktiske områder. Dette føyer seg til et mønster hvor det vies særlig oppmerksomhet 
til potensielle kinesiske investeringer i det høye nord, og det har i den forbindelse blitt klart uttalt at det er en prioritet å sikre nasjonalt eierskap til disse landområdene av potensiell strategisk betydning (Henriksen \& Berglund, 2014).

Den offentlige debatten kan illustreres ved å se nærmere på to eksempler som til sammen gir uttrykk for noen av hovedpunktene i det norske ordskiftet rundt kinesiske investeringer. For det første kan man ta for seg det kinesiske oppkjøpet av den profilerte norske bedriften Elkem som et eksempel på den jevnt over positive tilnærmingen til tilførselen av utenlandsk kapital fra Kina. Denne symbolsk tunge og økonomisk svært betydelige investeringen var typisk ved at den berørte en økonomisk sektor med liten sikkerhetspolitisk relevans. De bekymringene som kom til uttrykk, var dermed først og fremst rettet mot frykt for en underminering av norske arbeidsrettigheter, noe som i etterkant viste seg å være ubegrunnet, idet selskapet nå er betraktet som en svært "good case» på hvordan kinesisk kapital kan bidra til god industriutvikling i Norge (Fuest et al., u.d.; Hovland, 2018; Kristoffersen, 2019).

Gitt at det meste av kinesisk FDI til Norge, i likhet med oppkjøpet av Elkem, har vært i sektorer med begrenset sikkerhetsrelevans, er det som i så mange andre land det kinesiske teleselskapet Huawei som har blitt nøkkelcasen for spørsmål om avveiningen mellom økonomisk nytte og potensielle sikkerhetsutfordringer. Det er for øvrig på sin plass å presisere at Huawei ikke er en kinesisk direkteinvestering $\mathrm{i}$ Norge, men en greenfield-operatør. Dog er Huawei sin betydning og relevans så viktig at den meritterer spesiell oppmerksomhet uavhengig av investeringsmodalitet. Det er også dette selskapet som i den norske konteksten har vært gienstand for størst bekymring, og som derav har vært en viktig driver for de pågående debattene rundt nye reguleringer og screeningmekanismer for utenlandske investeringer i Norge.

\section{Den politiske debatten om investeringer, sikkerhet og screening}

Norge har tjent betydelig økonomisk, men også vært særegent utsatt for kinesisk maktbruk, med bakgrunn i Kinas nyvunne sterke økonomiske og politiske stilling i verden. Kinesisk FDI til Norge har lenge gått under radaren, idet de har vært av relativt begrenset omfang, av begrenset sikkerhetsrelevans og stort sett har vært gode eksempler på de positive sidene utenlandske kapitalstrømmer generelt kan bidra med. Imidlertid har debatten i de seneste par årene, drevet av Huaweisaken, nylig beveget seg rett inn i dette grunnleggende spenningsfeltet mellom økonomisk vinning og politisk og potensiell sikkerhetsmessig risiko.

Om den offentlige samtalen - og medienes oppmerksomhet - rundt kinesiske investeringer i Norge til dels har vært fraværende, har dog norske myndigheter i $ø$ kende grad rettet oppmerksomhet mot saksfeltet. Drevet frem av utviklinger på både globalt, europeisk og nordisk nivå har spørsmålet om kjøreregler for kinesiske kapitalstrømmer, spesielt i sikkerhetsmessig viktige sektorer, blitt drevet opp på det politiske sakskartet (se f.eks. Eriksen Søreide, 2019). Norge kjennetegnes, som sine nordiske naboer, av å være en åpen økonomi, og det gjøres i utgangspunktet få store 
distinksjoner mellom innenlandske- og utenlandske eiere. Det er en rekke generelle eierskaps- og markedsregulerende institusjoner og regelverk på plass, men disse utøves likt for alle relevante investorer. Sikkerhetsloven spesifiserer dog særskilte innrapporterings- og godkjenningsprosedyrer for investeringer i det som defineres som kritisk infrastruktur, uavhengig av om investeringene har nasjonalt eller utenlandsk opphav. En nylig sak som involverte et kinesisk konsortiums bud på en brobyggingskontrakt i Midt-Norge, satte søkelys på nettopp dette, da de lokale myndighetene valgte å diskvalifisere det kinesiske vinnerbudet på bakgrunn av at selskapet var basert utenfor EØS-området, og man henvendte seg til sentralmyndighetene for å få klargjort i hvilken grad dette utgjorde gyldig grunn for positivt å diskriminere europeiske selskaper (NRK, 2017b).

Flere norske investerings- og handelsavtaler inneholder spesialklausuler vedrørende nasjonalt eierskap i sektorer som petroleum og fiskeri, men per nå er det ingen særskilt screeningmekanisme på plass for utenlandske investorer som sådan. Ekspertkomiteen som i 2016 sluttførte en rapport om anbefalte oppdateringer i norsk sikkerhetslovgivning, konkluderte dog med at Norge trenger bedre beskyttelse mot utenlandsk eierskap i det som kan identifiseres som kritisk infrastruktur og viktige samfunnsfunksjoner (Botnan \& Lausund, 2016; Forsvarsdepartementet, 2016). Deres anbefaling innbefattet stiftelsen av en screeningmekanisme fundert på spesifikke og smalt definerte sikkerhetsmessige hensyn, med den begrunnelse at «myndighetene i dag ikke har tilstrekkelige virkemidler for å kunne sikre nasjonal kontroll med strategisk viktige selskaper» (Forsvarsdepartementet, 2016, s. 246).

Den videre politiske prosessen utviklet seg under ledelse av det norske Forsvarsdepartementet og ble endelig vedtatt i 2018 med virkning fra januar 2019 (Forsvarsdepartementet, 2018). I tillegg til en innstramming av reglene for anskaffelser innebærer dette nye legale rammeverket at norske myndigheter nå har fått adgang til å stanse oppkjøpet i tilfeller hvor det, i henhold til paragraf 10-3, er en «ikke ubetydelig risiko for at nasjonale sikkerhetsinteresser blir truet» (Justis- og beredskapsdepartementet, 2019). Paragraf 10-1 pålegger for dette formål en varslingsplikt på de relevante selskapene for oppkiøp tilsvarende minst en tredels eierandel. Dette innebærer for øvrig en terskel som ligger høyere enn hva tilfellet er for andre viktige økonomiske partnere for Norge, i særdeleshet Tyskland, der denne terskelen nylig ble senket til 25 prosent og til 10 prosent i spesielt strategiske sektorer (UNCTAD, 2018). Det er foreløpig ingen profilerte oppkjøpssaker som har blitt blokkert i henhold til dette nye regelverket, og det er dermed en del rom for fortsatt politisk debatt knyttet til hvordan denne lovgivningen vil operasjonaliseres i praksis.

\section{Konklusjon}

Som det eneste større nordiske landet utenfor EU, og som regionens eneste betydelige olje- og gasseksportør, er den norske politiske og økonomiske konteksten preget av noen til dels betydelige særegenheter sammenlignet med de andre nordiske 
landene. På mange måter er likevel Norges relasjoner til Kina et tilfelle som illustrerer, in extremis, flere av de grunnleggende felles utfordringene og dilemmaene de nordiske landene deler i sine forhold til Kina. For det første har norsk økonomi tjent særegent godt på det kinesiske veksteventyret over de siste to tiårene. For det andre har Norge også stått i en særegent vanskelig politisk stilling overfor Kina gjennom det siste tiåret. Disse hendelsene har også, naturlig nok, medført at spørsmålet om kinesiske investeringer i Norge har fått en ekstra betydelig politisk klangbunn. Kinas boikott har tydeliggjort de særegne utfordringene som følger med en stormakt som, i større grad enn vestlige land, lar økonomiske og handelspolitiske virkemidler inngå for å oppnå bredere utenrikspolitiske målsettinger. Kontrasten mellom disse to faktorene har stått sentralt i norsk Kina-debatt. Ikke desto mindre har den norske offentlige debatten rundt kinesiske investeringer vært relativt positiv. En rekke nyhetsartikler etter normaliseringen av relasjonene i 2016 gjenspeilet en forventning fra norske businessmiljøer, som så frem mot en gullalder for kinesiske kapitalstrømmer til Norge (som ikke kom). Dette har blant annet vært drevet frem av gode erfaringer blant norske selskaper som har blitt kjøpt opp av kinesiske partnere. Den offentlige samtalen har dog inntil nylig fokusert på kinesiske kapitalstrømmer til Norge, først og fremst som del av den positive økonomiske linsen, og har kun i nyere tid begynt å relatere til spørsmålet gjennom en politisk og sikkerhetsmessig vinkling.

Dette er et taktskifte som ikke skyldes hendelser knyttet til eksisterende kinesisk aktivitet i Norge men heller en norsk gjenspeiling av bredere globale og regionale trender. Huaweis rolle i den kommende utbyggingen av 5G-nettverket har vært et spesielt viktig bindeledd mot denne internasjonale opinionsdreiningen. Det økende fokuset på Huaweis rolle internasjonalt og blant norske sikkerhetsaktører har bidratt til at kritiske røster har latt seg høre i økende grad i den offentlige debatten de siste årene. Det faktum at dette opinionsskiftet har funnet sted i tandem med at norske myndigheter er i ferd med å sluttføre en frihandelsavtale med Kina, gjør sitt til at denne debatten neppe blir mindre politisk relevant i den nærmeste fremtid. De ennå ufullendte frihandelsforhandlingene med Kina er også et ekstra moment som setter Norge i en særegen stilling i den nordiske debatten om regulering av kinesiske investeringer. Dette gjelder ikke minst fordi man i skrivende stund også forhandler om å innta kapitler i avtalen som setter rammevilkår for bilaterale investeringer mellom landene (Stortingets europautvalg, 2019). Hvordan det endelige rammeverket for frihandelsavtalen vil bli seende ut, er, naturlig nok, ennå ikke klarlagt. Man kan dog allerede spore bekymrede stemmer i opinionen med tanke på at Norge kan befinne seg $i$ en svært sensitiv posisjon. Dette fordi man skal forhandle med Kina om en vidtrekkende avtale i en situasjon hvor både den globale og den nordiske posisjonen overfor Kina er i kraftig endring og de problematiske sidene ved kinesisk statskapitalisme har blitt stadig mer åpenbare. Norges posisjon som et Nato-land med sterke sikkerhetspolitiske bindinger til USA, i en situasjon hvor den amerikanske holdningen til kinesiske investeringer i sikkerhetsrelevante sektorer blir stadig mer restriktiv, er også et viktig bakgrunnsmoment som har endret seg radikalt siden frihandelsforhandlingene 
først ble igangsatt for over et tiår siden (se f.eks. Lysberg, 2019). I sum har dermed den vante norske antakelsen om at en frihandelsavtale er et økonomisk henseende uten bredere sikkerhetspolitisk relevans, kommet under stadig sterkere press.

Den norske posisjonen som et «utenforland» i forholdet til EU, innebærer dess mer at landet settes $i$ en spesielt utfordrende stilling overfor en stormakt som Kina. Norge har dermed ikke den institusjonelle muligheten de fleste andre nordiske stater har, til ekstensivt å benytte det europeiske nivået for å målbære sine interesser overfor Kina, slik dette senest ble formulert i den svenske regjeringens Kina-strategi (Government of Sweden, 2019). Dette utenforskapet åpner opp for muligheten til å forhandle med Kina direkte om bilaterale avtaler, en mulighet som ligger an til snart å bli mest kraftfullt illustrert gjennom den forventede sluttføringen av forhandlingene mellom Norge og Kina om en frihandelsavtale. Imidlertid innebærer dette mulighetsrommet også en sårbarhet, der det er naturlig å spørre seg om Kina ville ha boikottet et EU-medlem seks år i strekk, på samme måte som ble Norge til del. Selv om Norge ikke er EU-medlem, er landet tett tilknyttet EU gjennom EØS-avtalen og opprettholder tette bånd med de andre nordiske landene på tvers av alliansetilknytning. De politiske debattene som pågår i de andre nordiske landene vedrørende sikkerhetsavveininger rundt kinesiske investeringer, er derfor viktige også for Norge. For det første fordi de økonomiske vilkårene knesatt i EU får effekter i Norge gjennom EØS-avtalen, så et sentralt spørsmål her er hvordan endringer i det europeiske screeningregimet kan være relevante for Norge (Sverdrup, 2018). For det andre fordi det er naturlig for Norge å trekke på erfaringer og politiske prosesser fra «land vi liker å sammenligne oss med». I den sammenheng er det nyttig å merke seg at de andre nordiske landene i stor grad befinner seg i samme båt som Norge, i en verden hvor den åpne nordiske modellen blir utfordret på flere fronter.

\section{Om forfatterne}

Bjørnar Sverdrup-Thygeson er analytiker i Forsvarsstaben, og tidligere forsker ved Norsk Utenrikspolitisk Institutt (NUPI), med kinesisk politikk og internasjonale relasjoner som sitt fagfelt. Han avlegger sin PhD ved London School of Economics, etter studier i Oxford, Oslo og Kina.

Espen Mathy er statsviter med master fra Universitetet i Oslo og tidligere vitenskapelig assistent ved Norsk Utenrikspolitisk Institutt (NUPI).

\section{Bibliografi}

Aga, F. (2017, 18. august). Kinesiske storbanker ser mot norsk infrastruktur - signaliserte «investeringsgulv» på 100 millioner dollar. Bygg.no - Byggeindustrien. Hentet 18. august 2017 fra http://www.bygg.no/ article/1322831

Bekkevold, J. I. \& Kristoffersen, H. (2012). Kinas økonomi. Oslo: Gyldendal. Hentet 11. oktober 2016 fra http:// www.gyldendal.no/Faglitteratur/OEkonomi-og-administrasjon/Samfunnsoekonomi/Kinas-oekonomi 


\section{Bjørnar Sverdrup-Thygeson og Espen Mathy}

Botnan, J. I. \& Lausund, R. (2016). NOU 2016:19, Vedlegg 3:Vurdering av forebyggende sikkerhet innen kraft, petroleum og luftfart (s. 61). Kjeller: Forsvarets forskningsinstitutt.

Breian, Å. (2019, 16. mai). Huawei tilbyr «No-spy-agreement» dersom de får bygge ut 5G-nettet i Norge. Aftenposten. Hentet 20. mai 2019 fra https://www.aftenposten.no/article/ap-BRwqBe.html

Chen, X., Garcia, R. J. et al. (2015). China's Salmon Sanction. Hentet 27. mars 2015 fra http://www.nupi.no/ content/download/497772/1661097/version/2/file/WP-845-Chen-Garcia.pdf

Eriksen Søreide, I. (2019, 9. mai). Redegjørelse om viktige EU-EØS-saker 9. mai. Regjeringen.no. Taleartikkel. Hentet 20. oktober 2019 fra https://www.regjeringen.no/no/aktuelt/eu_redegjorelse190509/id2644259/

ETNC. (2017). Chinese Investment in Europe: A Country-Level Approach. Hentet 18. desember 2017 fra https:// www.ifri.org/fr/publications/publications-ifri/ouvrages-ifri/chinese-investment-europe-country-levelapproach

Fiskeridepartementet. (2019, 12. september). Fremgang i frihandelsforhandlingene mellom Norge og Kina. Regjeringen.no. Nyhet. Hentet 6. desember 2019 fra https://www.regjeringen.no/no/aktuelt/ny-side5/ id2668862/

Forsvarsdepartementet. (2016). Prop. 153 L (2016-2017) Proposisjon til Stortinget (forslag til lovvedtak) Lov om nasjonal sikkerhet (sikkerhetsloven).

Forsvarsdepartementet. (2016, 12. oktober). NOU 2016: 19. Regjeringen.no. NOU. Hentet 31. august 2017 fra https:/www.regjeringen.no/no/dokumenter/nou-2016-19/id2515424/

Forsvarsdepartementet. (2018, 20. desember). Ny sikkerhetslov skal gjøre Norge tryggere. Regjeringen.no. Pressemelding. Hentet 20. oktober 2019 fra https:/www.regjeringen.no/no/aktuelt/ny-sikkerhetslov/ id2623522/

Fuest, C., Hugger, F., Sultan, S. \& Xing, J. (u.d.). What Drives Chinese Overseas M\&A Investment? Evidence from Micro Data, 47.

Gåsemyr, H. J. (2018). Political values in Norway's relations with China: Standing ground or giving in? NUPI. Hentet 4. februar 2019 fra https://nupi/Publikasjoner/CRIStin-Pub/Political-values-in-Norway-srelations-with-China-Standing-ground-or-giving-in

Gåsemyr, H. J. \& Sverdrup-Thygeson, B. (2017). Chinese Investments in Norway: A Typical Case Despite Special Circumstances. Hentet 14. oktober 2019 fra https:/nupi.brage.unit.no/nupi-xmlui/handle/11250/2486829

Government of Norway \& Government of PRC. (2016). Statement of the Government of the People's Republic of China and the Government of the Kingdom of Norway on Normalization of Bilateral Relations. Hentet [dato] fra https:/www.regjeringen.no/globalassets/departementene/ud/vedlegg/statement_kina.pdf

Government of Sweden, M. (2019). Regeringens skrivelse 2019/20:18 - Arbetet i frågor som rör Kina, 21.

Havnes, H. (2017, 14. februar). Venter kinesisk oppkjøpsbølge. dn.no. Hentet 3. mai 2017 fra http://www. dn.no/nyheter/2017/02/13/1018/Utenriks/venter-kinesisk-oppkjopsbolge

Hellström, J. (2014). China's Political Priorities in the Nordic Countries. Hentet 8. august 2014 fra http://www. foi.se/ReportFiles/foir_3879.pdf

Hellström, J. (2016). China's Acquisitions in Europe: European Perceptions of Chinese Investments and their Strategic Implications (No. FOI-R--4384--SE). Swedish Defence Research Agency (FOI). Hentet 7. februar 2017 fra https:/foi.se/report-search/pdf?fileName=D:\%5CReportSearch\%5CFiles\%5C39d4c651-1562-48648554-7d7310408250.pdf

Henriksen, T. H. \& Berglund, E. L. (2014, 29. april). Ekspert om Svalbard-salg: - Kjøp kan gi Kina fotfeste i Arktis. VG. Hentet 31. august 2017 fra http://www.vg.no/a/10130869

Hovland, K. M. (2018, 24. mars). Industrigiganten har hatt kinesisk eier i syv år: - Ikke grunnlag for bekymringene. E24. Hentet 27. mars 2018 fra http://e24.no/a/24293553

Justis- og beredskapsdepartementet. (2019). Lov om nasjonal sikkerhet (sikkerhetsloven), Kapittel 10. Eierskapskontroll. Hentet 6. desember 2019 fra https://lovdata.no/dokument/NL/lov/2018-06-01-24/ KAPITTEL_10?q=sikkerhetsloven\#KAPITTEL_10

Kibar, O. (2019, 8. februar). Slik erobret Huawei det norske mobilnettet. DN Magasinet. Hentet fra https:// www.dn.no/magasinet/teknologi/teknologi/huawei/huawei-norge/slik-erobret-huawei-det-norskemobilnettet/2-1-539234

Kristoffersen, H. (2019). Kina: Utfordringer og muligheter for norsk næringsliv. Rapport for NHO, 40.

Laustsen, E. (2014, 28. oktober). "Griseflaksgrafen» som viser hvorfor Norge ble et søkkrikt land. Dagens Naringsliv. Hentet 26. juni 2017 fra https:/www.dn.nohttp://www.bisbuzz.no/2014/10/28/0821/Makro/ griseflaksgrafen-som-viser-hvorfor-norge-ble-et-skkrikt-land

Lier, G. (2011, 10. januar). LO kritisk til Elkem-salg. dn.no. Hentet 31. august 2017 fra https://www.dn.no/ nyheter/naringsliv/2011/01/10/lo-kritisk-til-elkemsalg 
Lohne, A. K. J. (2017, 9. juni). Statoil inngår avtale med kinesisk oljegigant. Aftenposten. Hentet 9. juni 2017 fra http://www.aftenposten.no/article/ap-622862b.html

Lohne, J. (2017, 7. april). Kina og Norge venner igjen: Erna Solberg mottatt med pomp og prakt i Beijing. Aftenposten. Hentet 14. juni fra http://www.aftenposten.no/article/ap-618930b.html

Lysberg, M. (2019, 4. desember). Nærmer seg Kina-avtale. Klassekampen. Hentet 6. desember 2019 fra https:// www.klassekampen.no/article/20191204/ARTICLE/191209989

Melchior, A. (2018). Trade, USA and the Rise of China: Pains and Gains. I A. Melchior (Red.), Free Trade Agreements and Globalisation: In the Shadow of Brexit and Trump (s. 115-130). Cham: Springer International Publishing. Hentet fra https://doi.org/10.1007/978-3-319-92834-0_7

NRK. (2017a, 10. april). Slik endrer Solberg-besøket forholdet til Kina. NRK. Hentet 10. april 2017 fra https:// www.nrk.no/norge/slik-endrer-solberg-besoket-forholdet-til-kina-1.13469385

NRK. (2017b, 31. oktober). Trøndersk forsøk på Kina-boikott vekker oppsikt. NRK. Hentet 31. oktober 2017 fra https://www.nrk.no/norge/trondersk-forsok-pa-kina-boikott-vekker-oppsikt-1.13757508

NRK. (2019, 10. januar). Huawei kan bli utestengt fra norsk 5G-utbygging. NRK. Hentet 11. januar 2019 fra https://www.nrk.no/norge/huawei-kan-bli-utestengt-fra-norsk-5g-utbygging-1.14373969

NTB. (2017, 14. februar). Norge kan vente kinesiske oppkjøp og investeringer. E24. Hentet 31. august 2017 fra http://e24.no/a/23924215

NTB. (2019, 19. mai). Ny lakseavtale mellom Norge og Kina. dn.no. Hentet 19. mai 2019 fra https://www. dn.no/handel/ny-lakseavtale-mellom-norge-og-kina/2-1-606106

NUPI. (2019, 6. mars). Huawei: En risiko eller ikke? Hentet 8. mars 2019 fra https://NUPI./Arrangementer/2019/ Huawei-En-risiko-eller-ikke

Øgrim, H. \& Nilsen, K. A. (2015). Kina vs. Norge: Den ukjente historien fra Maos nei til dagens krise. Oslo: Kagge Forlag. Hentet 11. oktober 2016 fra http://www.kagge.no/index.cfm?tmpl=butikk\&a=product_inline\&b_ kid $=1044808 \& b \_i d=1584310$

Stortingets Europautvalg. (2019, 14. mars). Møte i Europautvalget torsdag den 14. mars 2019 - Sak nr. 2. Stortinget. Europautvalget. Hentet 6. desember 2019 fra https://www.stortinget.no/no/Saker-ogpublikasjoner/Publikasjoner/Referater/Europautvalget/2018-2019/refe-201819-03-14/?m=2

Sverdrup, U. (2018, 18. juni). Investeringer og sikkerhet: Norge bør koble seg til EUs nye investeringsregime.

Sverdrup-Thygeson, B. (2015). The Flexible Cost of Insulting China: Trade Politics and the "Dalai Lama Effect". Asian Perspective, 39(1), 101-123.

Sverdrup-Thygeson, B. (2017). The Norway-China Relationship: For Better, For Worse, For Richer, For Poorer. I B. Sverdrup-Thygeson, W. Y. Lindgren \& M. Lanteigne (Reds.), China and Nordic Diplomacy (s. 77-100). Oxon: Routledge.

UNCTAD. (2018, 19. desember). Germany expands the scope of its FDI screening regime. Investment Policy Monitor - UNCTAD Investment Policy Hub. Hentet 6. desember 2019 fra https://investmentpolicy. unctad.org/investment-policy-monitor/measures/3337/germany-germany-expands-the-scope-of-its-fdiscreening-regime

Utenriksdepartementet. (2011, 11. oktober). Norge og Kina. Regjeringen.no. Taleartikkel. Hentet 2. juni 2016 fra https://www.regjeringen.no/no/aktuelt/norge_kina/id660339/

\section{Abstract in English \\ Norway's Debate about Chinese Investments: From Benevolence to Caution}

The debate in Norway regarding security concerns related to Chinese investments has seen a notable change in character over a short period of time. From a situation where there was little discernible debate at all, and where negative coverage of Chinese investment flows were mainly concerned with working environment issues, Chinese capital flows to Norway have now also become part of the debate on national security. Two particularities make the case of Norway especially interesting with regards to the broader Nordic debates over the issues discussed in this Fokus section. The Norwegian economy has been particularly well placed to benefit from the extraordinary Chinese economic 
growth, but Norway has also been in a particularly problematic political position towards China over the last decade. The contrast between these two factors has been a structuring trait of the Norwegian China debate. Nevertheless, the Norwegian public debate on China has been relatively positive over a long period of time. This has been given impetus by the positive experiences reported from the Norwegian enterprises that have been the target of Chinese acquisitions. However, lately, the public debate has increasingly come to regard the issue also through a political and security-related lens. This changing character is not due to specific events concerning Chinese activities in Norway, as much as being a reflection of broader regional and global trends. The question of Huawei's role in the coming construction of the 5G network has been a particularly important driver in this regard, as well as conductive link to the international change in opinion.

Keywords: investments $\cdot$ security $\cdot$ economy $\cdot$ Norwegian foreign policy $\cdot$ China 